\title{
SIMULATION MODEL OF LOGISTICS SYSTEM
}

\author{
Svilen Stefanov ${ }^{1}$, Venelin Terziev ${ }^{2}$, Vanya Banabakova ${ }^{3}$ \\ ${ }^{1}$ Prof, Ph.D., National Military University, Veliko Tarnovo, Bulgaria, sestefanov@abv.bg \\ ${ }^{2}$ Corresponding Member of the Russian Academy of Natural History, Moscow, Russia, Prof. \\ D.Sc. (Ec.), D.Sc. (National Security), D.Sc. (Social Activities), Ph.D., National Military University, \\ Veliko Tarnovo, Bulgaria; University of Rousse, Rousse, Bulgaria, terziev@skmat.com \\ ${ }^{3}$ Prof. Ph.D., National Military University, Veliko Tarnovo, Bulgaria, email: v.banabakova@abv.bg
}

\begin{abstract}
The goal of the article is to research the information exchange speed's influence on the effectiveness of the organization.

It is necessary to model the entire work of the logistic system in order to study the influence of the information flow. This includes raw materials supply, product manufacture, distribution on the market and selling to the end customers. The model should include all three flows that are characteristic of logistic chains: material, cash flow and information. This would allow observing its functioning in its integrity. Besides, basic indicators of effective functioning of such type of systems are the profit realized in the separate chain elements and the number of unsatisfied customers, i.e. the profits foregone.

The aim of the model is, setting different values for information exchange and procession speed, to observe the changes in the system's indicators the way they were mentioned above. The relevant conclusions would be made on the base of the received results. All the other system's parameters would have the same values within the planned numeral experiments.
\end{abstract}

Keywords: simulation model, information, logistics system.

\section{INTRODUCTION}

Information exchange and procession speed exercises significant influence on the logistic system functioning. A computer simulation model is elaborated to verify that statement.

It is necessary to model the entire work of the logistic system in order to study the influence of the information flow. This includes raw materials supply, product manufacture, distribution on the market and selling to the end customers. The model should include all three flows that are characteristic of logistic chains: material, cash flow and information. This would allow observing its functioning in its integrity. Besides, basic indicators of effective functioning of such type of systems are the profit realized in the separate chain elements and the number of unsatisfied customers, i.e. the profits foregone.

The aim of the model is, setting different values for information exchange and procession speed, to observe the changes in the system's indicators the way they were mentioned above. The relevant conclusions would be made on the base of the received results. All the other system's parameters would have the same values within the planned numeral experiments. 


\section{DESCRIPTION OF THE MODEL}

The multi-agent systems software tool is chosen for the development of the model. The concrete realization is performed in NetLogo programming environment. It is meant for developing multi-agent systems and it is software with free license.

The model's graphic interface is shown on Figure 1.

The model's workspace shown in the middle of Figure 1, is divided into two zones: market - marked in blue, and production zone - marked in black.

The following agents are included in the model:

Consumer - presented in the workspace as small yellow men-figures. Each one of them has expectations about the product's price. It is generated as random number with normal distribution.

Consumers move along random trajectories within the market (the blue area). When someone of them gets in the distribution centre, he checks whether the price corresponds to his expectations, i.e. whether it is lower or equal to them. Besides that, it is checked whether the distributor has the demanded product available. If these conditions are fulfilled, the customer buys a unit of the production. No matter whether he made the purchase or not, the customer disappears from the market and a new one is generated - with a new requirement for price.

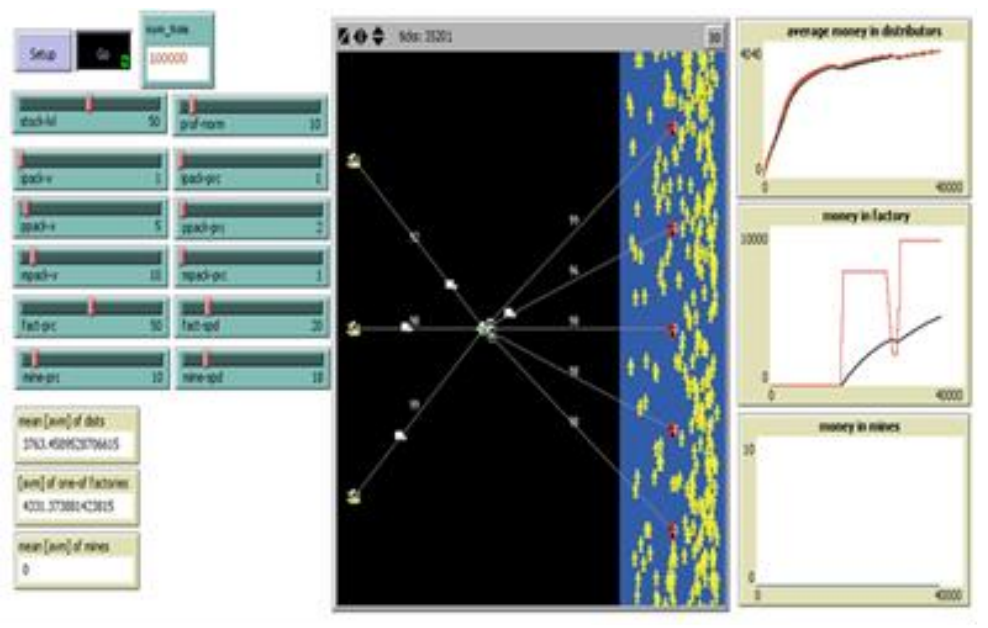

Fig.1. Model's graphic interface

Distributors - they are shown in the workspace as small red houses. In the beginning of the simulation, each distributor has certain quantity of production (50 units). When a customer purchases from the product, the availability reduces by a unit and distributor's money increase by the relevant price. When the number of available products drops under a certain level, the distributor sends an order to the manufacturer for filling up. At receiving the production, the distributor sends financial means to the manufacturer, corresponding to the product's wholesale price and to the delivered quantity. All expenses for sending information (orders), transport of material means and for financial transactions are at the expense of the distributor.

Manufacturer - he is presented in the graphic model as a factory in green in the middle of the workspace. Three types of raw material are necessary for the production of a unit of production. In the beginning of the simulation, the manufacturer preserves certain amounts ready production of each type of raw materials (500 units of each). At getting the order from the distributors, the manufacturer sends them the ordered quantities of production, by which his availability is reduced. The manufacturing starts, when it drops under a certain level. Manufacturing costs certain monetary means and in order to be realized, the following circumstances should be fulfilled: there to be availability of all necessary raw materials and the relevant financial means to be available. Besides, the raw materials stock reduces. When it reduces under certain level, an order is send to the relevant raw materials producer (supplier). At receiving the ordered items, their value has been returned as monetary reimbursement. The necessary financial means for communication are at the expense of the manufacturer.

Supplier - it is presented graphically in the model's workspace as factories in yellow. They produce the raw materials necessary for the final product. The production costs certain monetary means. Suppliers possess stock of raw materials in the beginning of the simulation. At getting order from the manufacturer, they complete it and when the level of reserve drops under certain level, they start producing. In order that to 
happen they should have available the necessary financial means.

Information packages - these are the orders for supply of necessary products by the relevant agent to another agent, who possesses the necessary resource. They characterize with certain speed and cost of moving. They are graphically presented as white envelopes.

Material packages - these are material supplies in pursuance of the ordered quantities. They are graphically presented as white trucks. When the sender does not possess the necessary quantity to fulfill an order, its fulfillment stops and waits until the necessary material means are supplied.

Monetary packages - they are presented as green banknotes. These are the payments realized after receiving the ordered quantities of material resources. They transfer monetary means from the sender to the recipient. The relevant quantity of financial means is subtracted from the sender's money and at arriving is added to the recipient's money.

Connections between the agents - they are presented as straight lines connecting the separate agents in the model. They play the role of paths and possess a characteristic - length or distance between the agents, shown as a number above them.

The model's graphic interface includes, besides the graphic space situated in the middle, the following elements - Table 1.

Table 1.Logistic system simulation model graphic interface's elements

\begin{tabular}{|c|c|}
\hline Element & Interface element's function \\
\hline Button Setup & $\begin{array}{l}\text { Prepares the model for work, features the } \\
\text { separate elements in the workspace and others. }\end{array}$ \\
\hline Button Go & It starts the model's work. \\
\hline Field num-ticks & $\begin{array}{l}\text { It sets the number of ticks (cycles), through which } \\
\text { the model would work. When the ticks' counter } \\
\text { reaches this value, the model stops to work. }\end{array}$ \\
\hline Cursor stock-lvl & $\begin{array}{l}\text { It sets in percentages the level of stock, at which } \\
\text { reaching an order for filling up is sent. All agents } \\
\text { use this level and the level of stock is calculated } \\
\text { as percentage of the initial quantity, with which } \\
\text { the simulation starts. }\end{array}$ \\
\hline Cursor prof-norm & $\begin{array}{l}\text { It sets in percentages norm of profit for all agents } \\
\text { in the model. Everybody accrues these monetary } \\
\text { means over the sold product's prime cost. }\end{array}$ \\
\hline Cursor ipack-v & $\begin{array}{l}\text { It sets speed of the information packages' } \\
\text { movement. Value } 1 \text { means movement of the } \\
\text { package at a distance of a unit for one tick (cycle) } \\
\text { of the model's work. }\end{array}$ \\
\hline Cursor ipack-prc & $\begin{array}{l}\text { It sets the cost for the information packages' } \\
\text { moving at a distance of a unit. }\end{array}$ \\
\hline $\begin{array}{l}\text { Cursors ppack-v } \\
\text { and ppack-prc }\end{array}$ & $\begin{array}{l}\text { It sets relevantly speed and cost of the material } \\
\text { packages' moving. }\end{array}$ \\
\hline $\begin{array}{l}\text { Cursors mpack-v } \\
\text { and mpack-prc }\end{array}$ & $\begin{array}{l}\text { They set relevantly speed and cost of monetary } \\
\text { packages' moving. }\end{array}$ \\
\hline $\begin{array}{l}\text { Cursor fact-prc and } \\
\text { fact-spd }\end{array}$ & $\begin{array}{l}\text { They set relevantly the necessary financial } \\
\text { means for the production of a unit of final product } \\
\text { and the speed for the production of a unit of final } \\
\text { product in number of ticks. The price includes } \\
\text { also the value of the raw materials set in the } \\
\text { product. }\end{array}$ \\
\hline $\begin{array}{l}\text { Cursor mine-prc and } \\
\text { mine-spd }\end{array}$ & $\begin{array}{l}\text { They present relevantly price and necessary time } \\
\text { for producing a unit of raw materials. It is } \\
\text { accepted in the model that all raw materials are } \\
\text { produced at same value and for the same time. }\end{array}$ \\
\hline $\begin{array}{l}\text { Deduction field } \\
\text { mean [avm] of dists }\end{array}$ & $\begin{array}{l}\text { It shows the average profit of the final product's } \\
\text { distributors for the market. }\end{array}$ \\
\hline Deduction field & It shows time-averaged value of producer's profit. \\
\hline
\end{tabular}




\begin{tabular}{|l|l|}
\hline \multicolumn{1}{|c|}{ Element } & \multicolumn{1}{c|}{ Interface element's function } \\
\hline $\begin{array}{l}\text { [avm] of one-of } \\
\text { factories }\end{array}$ & \\
\hline $\begin{array}{l}\text { Deduction field } \\
\text { mean [avm] of } \\
\text { mines }\end{array}$ & $\begin{array}{l}\text { It shows the average profit of the raw materials } \\
\text { suppliers. }\end{array}$ \\
\hline $\begin{array}{l}\text { Graphic average } \\
\text { money in } \\
\text { distributors }\end{array}$ & $\begin{array}{l}\text { It shows the passing values of distributors' profit, } \\
\text { averaged by time. }\end{array}$ \\
\hline $\begin{array}{l}\text { Graphic money in } \\
\text { factory }\end{array}$ & $\begin{array}{l}\text { It shows the passing values of the available } \\
\text { financial means in the producer (red) and his } \\
\text { averaged by time profit (black line). }\end{array}$ \\
\hline $\begin{array}{l}\text { Graphic money in } \\
\text { mines }\end{array}$ & $\begin{array}{l}\text { It shows the passing values of raw materials } \\
\text { suppliers' profit. }\end{array}$ \\
\hline
\end{tabular}

\section{NUMERAL EXPERIMENT, RESULTS}

For verification of the statement that the speed of movement and procession of information exercises significant influence upon the work and effectiveness of the entire logistic system, a numerical experiment is planned. At constant values of all rest perimeters, only the speed of moving of information packages is changing. The following indicators are chosen for starting indicators for the logistic system's work: average profit of the distributors, producer's profit, average profit of the raw materials' suppliers and number of missed sales because of lack stock in the relevant distributor.

It is planned experiments to be held at speeds of information packages moving of $1,2,5,10,20,50,100$. As far as number of elements cannot be generated as random numbers while preparing the model, for example the distances between the objects and others, three simulations are conducted for each value of speed, and the resulting values for the separate indicators are averaged.

The results of all conducted numeral experiment are shown in Table 2.

Table 2. Results of the numeral experiments

\begin{tabular}{|c|c|c|c|c|c|}
\hline $\begin{array}{l}\text { Speed of } \\
\text { information } \\
\text { exchange }\end{array}$ & Trials & $\begin{array}{l}\text { Average profit } \\
\text { of distributors }\end{array}$ & $\begin{array}{l}\text { Average } \\
\text { profit of } \\
\text { producers }\end{array}$ & $\begin{array}{l}\text { Average } \\
\text { profit of } \\
\text { suppliers }\end{array}$ & $\begin{array}{l}\text { Sales } \\
\text { forgone }\end{array}$ \\
\hline \multirow{4}{*}{1} & 1 & 4672 & 7863 & 318 & 4880 \\
\hline & 2 & 4609 & 7293 & 316 & 4801 \\
\hline & 3 & 4628 & 7631 & 319 & 4569 \\
\hline & Average & 4636 & 7596 & 318 & 4750 \\
\hline \multirow{4}{*}{2} & 1 & 5354 & 8898 & 618 & 3922 \\
\hline & 2 & 5376 & 9023 & 620 & 4003 \\
\hline & 3 & 5339 & 9076 & 615 & 3875 \\
\hline & Average & 5356 & 8999 & 618 & 3933 \\
\hline \multirow{4}{*}{5} & 1 & 6667 & 10787 & 1008 & 2530 \\
\hline & 2 & 6643 & 10428 & 970 & 2488 \\
\hline & 3 & 6517 & 9593 & 1024 & 2436 \\
\hline & Average & 6609 & 10269 & 1001 & 2485 \\
\hline \multirow{4}{*}{10} & 1 & 7439 & 10944 & 1283 & 1520 \\
\hline & 2 & 7443 & 10242 & 1282 & 1429 \\
\hline & 3 & 7650 & 10587 & 1353 & 1445 \\
\hline & Average & 7511 & 10591 & 1306 & 1465 \\
\hline \multirow{2}{*}{20} & 1 & 7840 & 10989 & 1522 & 917 \\
\hline & 2 & 7992 & 10870 & 1492 & 903 \\
\hline
\end{tabular}




\begin{tabular}{|c|l|l|l|l|l|}
\hline $\begin{array}{c}\text { Speed of } \\
\text { information } \\
\text { exchange }\end{array}$ & Trials & $\begin{array}{c}\text { Average profit } \\
\text { of distributors }\end{array}$ & $\begin{array}{c}\text { Average } \\
\text { profit of } \\
\text { producers }\end{array}$ & $\begin{array}{c}\text { Average } \\
\text { profit of } \\
\text { suppliers }\end{array}$ & $\begin{array}{c}\text { Sales } \\
\text { forgone }\end{array}$ \\
\hline \multirow{5}{*}{50} & 3 & 7701 & 10259 & 1484 & 1001 \\
\cline { 2 - 6 } & Average & 7844 & 10706 & 1499 & 940 \\
\hline \multirow{5}{*}{5} & 1 & 8196 & 11230 & 1671 & 432 \\
\cline { 2 - 6 } & 2 & 8323 & 11179 & 1639 & 438 \\
\cline { 2 - 6 } & 3 & 8526 & 10602 & 1651 & 327 \\
\hline \multirow{5}{*}{100} & Average & 8348 & 11004 & 1654 & 399 \\
\cline { 2 - 6 } & 1 & 8499 & 10715 & 1671 & 234 \\
\cline { 2 - 6 } & 2 & 8521 & 10943 & 1674 & 205 \\
\cline { 2 - 6 } & 3 & 8632 & 11789 & 1691 & 288 \\
\cline { 2 - 6 } & Average & 8551 & 11149 & 1679 & 242 \\
\hline
\end{tabular}

Table 3.shows the averaged values of the chosen indicators.

Table 3.Averaged indicators' values

\begin{tabular}{|c|c|c|c|c|}
\hline $\begin{array}{c}\text { Speed of } \\
\text { information } \\
\text { exchange }\end{array}$ & $\begin{array}{c}\text { Average profit } \\
\text { of the } \\
\text { distributors }\end{array}$ & $\begin{array}{c}\text { Average profit } \\
\text { of the } \\
\text { producer }\end{array}$ & $\begin{array}{c}\text { Average } \\
\text { profit of the } \\
\text { suppliers }\end{array}$ & $\begin{array}{c}\text { Sales } \\
\text { forgone }\end{array}$ \\
\hline 1 & 4636 & 7596 & 318 & 4750 \\
\hline 2 & 5356 & 8999 & 618 & 3933 \\
\hline 5 & 6609 & 10269 & 1001 & 2485 \\
\hline 10 & 7511 & 10591 & 1306 & 1465 \\
\hline 20 & 7844 & 10706 & 1499 & 940 \\
\hline 50 & 8348 & 11004 & 1654 & 399 \\
\hline 100 & 8551 & 11149 & 1679 & 242 \\
\hline
\end{tabular}

The results shown in the table are presented graphically in Figure 2.

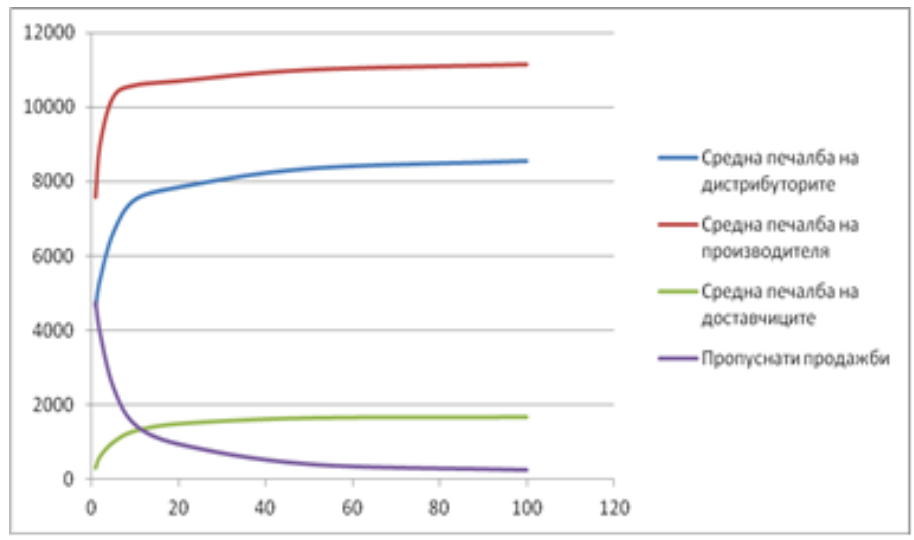

Fig 2.Graphics of the chosen indicators depending on the speed of information exchange

\section{CONCLUSION}

The following basic conclusions can be drawn from the conducted numeral experiment (Anikin, 1999a; Belozubov, Nikolaev, 2007a; Banchev, 2010a; Banabakova, 2012a; Banabakova, 2013a; Banabakova, Panev, 2012b; Banabakova, 2004a; Daskalova, Grigorova, 2012c; Dimitrov, 2010b; Baker, Fuller, 2009a; Faulkner, 2000a; Floridi, 2010c; Ganeshkumar, 2006a; Haine, 2011a; Hilbert, 2011b; Banzhaf, 1998a; Goldberg, 1989a; Michalewicz, 1999b; Mitchell, 1996a; Vose, 1999c): 
The speed of information exchange and processing exercises serios influence upon the logistic system's work. The results in Figure 2. Show that the profit of the separate elements of the system increase at higher values of the information exchange speed.

"Saturation" of the starting indicators, i.e. their increase reduces at higher values of information speed (Figure 2.) when increasing he information exchange speed within the logistic system. Hence, balance between the invested means for information exchange improvement and the value of profit should be looked for.

The suggested logistic system simulation model is applicable for the Bulgarian army logistic system, too.

Is it is this option of the model, the agents would be as follows: suppliers; storehouses of the Bulgarian army; military formations; information packages; material packages; monetary packages; connections between the agents.

The goal of the simulation model would be studying the speed of information exchange and procession upon the time for execution of supplies and logistic expenses, as far as these indicators are of crucial significance for the Bulgarian army logistic system functioning.

\section{REFERENCE LIST}

Anikin, B. i kol. (1999a). Logistika. Izd. Feniks, Moskva. 1999 (Аникин, Б. и кол. Логистика. Изд. Феникс, Москва. 1999).

Belozubov, A., Nikolaev, D. (2007a). Osnovay rabotay s HTML - redaktorom Adobe Dreamweaver CS3, Uchebno-metodicheskoe posobie, Sankt-Peterburg 2007 (Белозубов, А., Николаев, Д. Основы работы с HTML - редактором Adobe Dreamweaver CS3, Учебно-методическое пособие, СанктПетербург 2007).

Banchev, P. (2010a). Pazarni prouchvaniya. Izd. Faber. Veliko Tarnovo. 2010 (Банчев, П. Пазарни проучвания. Изд. Фабер. Велико Търново. 2010).

Banabakova, V. (2012a). Stopanska logistika. Izd. Faber. Veliko Tarnovo. 2012 (Банабакова, В. Стопанска логистика. Изд. Фабер. Велико Търново. 2012).

Banabakova, V. (2013a). Logistichnoto obsluzhvane kato iztochnik na konkurentni predimstva. IK pri NVU, Veliko Tarnovo. 2013 (Банабакова, В. Логистичното обслужване като източник на конкурентни предимства. ИК при НВУ, Велико Търново. 2013).

Banabakova, V., Panev, A. (2012b). Znachenie na biznes informatsionnite sistemi i tehniya odit za podobryavane na stopanskata deynost. Sp. Nauka, Br. 1, S., 2012 (Банабакова, B., Панев, A. Значение на бизнес информационните системи и техния одит за подобряване на стопанската дейност. Сп. Наука, Бр. 1, С., 2012).

Banabakova, V. (2004a). Logistika - aspekti na prilozhenie v ikonomicheskata i voenna sistema. IK pri NVU. Veliko Tarnovo. 2004 (Банабакова, В. Логистика - аспекти на приложение в икономическата и военна система. ИК при НВУ. Велико Търново. 2004).

Daskalova, H., Grigorova, V. (2012c). Izsledvane na integratsiyata na korporativni resheniya kato usluga. International Journal "Information Theories \& Applications", Vol. 13, S. 2012 (Даскалова, X., Григорова, В. Изследване на интеграцията на корпоративни решения като услуга. International Journal "Information Theories \& Applications", Vol. 13, C. 2012).

Dimitrov P. i kol. (2010b). Logistichni sistemi. UI “Stopanstvo”, 2010 (Димитров П. и кол., Логистични системи. УИ “Стопанство", 2010).

Baker, D. Fuller, L. (2009a). How to Do Everything, Adobe® InDesign® CS4, USA, 2009.

Faulkner, X. (2000a). Usability engineering, Haundmills, Palgrave, 2000.

Floridi, L. (2010c). A Very Short Introduction. Oxford University Press, 2010.

Ganeshkumar, M. (2006a). Refine The Economics of Integration. Whitepaper. Rising Solutions, USA, 2006.

Haine, P. (2011a). HTML Mastery: Semantics, Standards, and Styling, USA, 2011. 
Hilbert, M. (2011b). The World's Technological Capacity to Store, Communicate, and Compute Information. // Science 332 (6025), USA, 2011.

Banzhaf, W. (1998a). Genetic Programming - An Introduction, Morgan Kaufmann, San Francisco, 1998.

Goldberg, D. (1989a) Genetic Algorithms in Search, Optimization and Machine Learning, Kluwer Academic Publishers, Boston, 1989.

Michalewicz, Z. (1999b). Genetic Algorithms + Data Structures = Evolution Programs, Springer-Verlag, Cambridge, 1999.

Mitchell, M., (1996a). An Introduction to Genetic Algorithms, MIT Press, Cambridge, 1996.

Vose, M. (1999c). The Simple Genetic Algorithm: Foundations and Theory, MIT Press, Cambridge, 1999. 